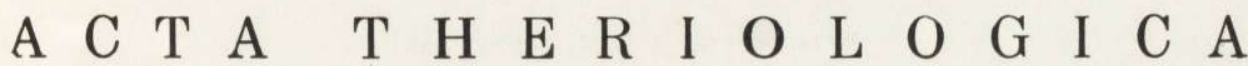 \\ VOL. XVI, 22: $359-369$. \\ BIAŁOWIEŻA \\ November, 1971
}

\author{
Zofia G E B C Z Y Ń K A \& Marek G E B C Z Y Ń S K I
}

\section{Length and Weight of the Alimentary Tract of the Root Vole}

\author{
[With 2 Tables \& 2 Figs.]
}

\begin{abstract}
Measurements were made of the length and weight of the alimentary tract (without the esophagus) in 282 individuals of Microtus oeconomus, at different seasons. These were both young, sexually immature individuals and adult, sexually mature animals, including pregnant and nursing females. The length and weight of the alimentary tract increase with age, but this increase proceeds more slowly than growth of the whole body. In young voles the alimentary tract is relatively larger than in older individuals. In nursing females the length and weight of the alimentary tract are greater than in pregnant females. Hypertrophic changes during gestation and lactation are greatest in those species of rodents feeding on concentrated diets, and the size of their alimentary tracts is relatively small (rat, Apodemus flavicollis). These changes ar€ smaller in rodents feeding on both concentrated and bulky foods and which possess relatively larger alimentary tracts (Clethrionomys glareclus). They are most weakly expressed in $M$. oeconomus, a typical graminivore with a large alimentary tract.
\end{abstract}

\section{INTRODUCTION}

The alimentary tract in rodents is characterized by considerable morphological variation, and its length and weight depend primarily on food specialization (V o r o n t s o v, 1967). These characters also vary with the animals' age (M y r c h a, 1964; V or on t s ov, 1967). It is of special interest here that the alimentary tract in pregnant and nursing females exhibits periodical increases in length and hypertrophy of the walls. This phenomenon was investigated using a female rat example (cf. Fell, $\mathrm{S} \mathrm{m}$ it h \& C a m p b e ll, 1963), and later was also described in the bank vole (M y r ch a, 1964) and yellow-necked field mouse (M y r h a, 1965).

Investigations have not so far been made of the length and weight of the alimentary tract of the root vole, Microtus oeconomus $\mathrm{P}$ a 11 a s, 1776 , and the changes taking place in it in connection with age and sexual activity. Only Vor on t s ov (1962) gives the relative length of the intestines and their relation to body length. Parallel to studies on food re- 
quirements, preferences and digestibility ( $G$ ę b c z y ń s k a, 1970), measurements were also made of the lenght and weight of different parts of the intestines and weight of the stomach at different seasons of the year. Studies were made of both young, sexually immature and also adult individuals some of the latter being sexually active females. Measurements of this sort make it possible to estimate whether, and to what degree, the alimentary tract in the root vole, a typical graminivorous species, undergoes changes depending on the season, and age and physiological state of the animal. The root vole was also compared with the rat, yellow-necked field mouse and bank vole - species with different food preferences.

\section{MATERIAL AND METHODS}

A total of 282 individuals were used for the studies, 81 of which were pregnant or nursing female root voles, caught in a sphagnum bog in a wooded area in the Augustów Forest. The voles were usually caught alive in pitfalls (B u chal c z y k \& P u cek, 1968), and were killed after reaching the laboratory. The alimentary tract contained food in the case of both live and dead animals in the pitfalls.

Table 1

Number of voles examined in different seasons, excluding pregnant and nursing females (average body weight given in brackets).

\begin{tabular}{|l|c|c|c|c|c|c|}
\hline \multirow{2}{*}{ Season } & \multicolumn{6}{|c|}{ Body weight class } \\
\cline { 2 - 7 } & $10.0-19.9$ & $20.0-29.9$ & $30.0-39.9$ & $40.0-49.9$ & $50.0-59.9$ & $60.0-69.9$ \\
\hline Spring & 7 & 16 & 9 & 11 & - & - \\
& $(15.8)$ & $(24.6)$ & $(34.7)$ & $(45.3)$ & - & - \\
Summer & 7 & 22 & - & 8 & 10 & 6 \\
& $(18.1)$ & $(23.6)$ & - & $(46.9)$ & $(55.6)$ & $(61.7)$ \\
Autumn & 8 & 35 & 10 & 21 & - & - \\
& $(18.6)$ & $(23.5)$ & $(36.4)$ & $(44.9)$ & - & - \\
Winter & 16 & 15 & - & - & - & - \\
& $(18.0)$ & $(24.1)$ & - & - & - & - \\
\hline
\end{tabular}

Measurements were made in the laboratory of body length and weight, state of sexual activity, after which the alimentary tract was excised (less the esophagus). Length of the intestines was measured on fresh material with accuracy to $0.1 \mathrm{~cm}$. Measurements were made after stretching the alimentary tract on a glass plate, in a normal saline solution, which prevented dehydration of the intestines and variations in their length due to possible stretching. The various parts of the intestines and the stomach were next weighed on a torsion balance with accuracy to $0.001 \mathrm{~g}$, after having been previously cleaned of food residue and dried from the normal saline solution. The material obtained, after excluding sexually active females, was divided into groups every $10 \mathrm{~g}$, depending on the body weight of the individuals examined (Table 1). Statistical analysis was made of the results obtained by means of the $t$-Student, comparing the average values for two independent groups. The absence of statistically significant differences $(P>0.05)$ between males and females 
in all groups (excluding sexually active females) made it possible to give the average values for the two sexes jointly.

\section{RESULTS}

\section{Seasonal and Age Changes in Length and Weight of the Alimentary Tract}

Differences in the length of the intestines depending on the group are observed in all seasons. This value is always greater in the groups of heavier animals, that is older animals, than in younger animals (Fig. 1). This shows that the alimentary tract increases in length with age.

In spring the totai length of the intestines, like their various parts, differ $(0.01<\mathrm{P}<0.05)$ within the first groups. In group $I V$, on the other hand, although increased length can be observed, this value does not differ significantly from the data for group III. In voles caught in summer the relations in respect of length of the alimentary tract are different. Only the total length of the intestines is significantly higher statistically in the second group in comparison with group $I$. The absence during this period of animals weighing between $30.0-39.9$ results in the corresponding values compared between groups $I I$ and $I V$ differing greatly $(\mathrm{P}<0.01)$. This applies both to the various parts of the intestines and to their total length. The differences existing between voles weighing over $40.0 \mathrm{~g}$ are not statistically significant. In autumn also, as in spring increase in intestinal length is most rapid in animals weighing not more than $39.9 \mathrm{~g}$. The differences between the first three groups are thus also significant. Later the rate of increase in intestinal length slows down and animals allocated to group $I V$ do not differ significantly from the preceding group. In winter also animals in group $I I$ have significantly longer intestines than those in group $I$.

In addition to changes with age it is also possible to observe some seasonal variations in intestinal length. Speaking generally it may be said that the total intestinal length in the respective age groups is greatest in summer and lowest in spring. Intermediate values are found in autumn and winter (Fig. 1).

Relative length (index) of the intestines was assessed in relation to body length. In this way it proved possible to establish that this index is in principle higher in groups lighter in weight, although complete regularity is found only in spring. In summer this regularity is subject to some disturbance (Fig. 1). In autumn and winter, however, the index is uniform in all the groups, except for voles in group II caught in autumn, in which this index is far higher (Fig. 1).

A change in the weight of the intestines and stomach is more strongly marked in different groups of voles (Fig. 2) than the change in intestinal 
length. In spring differences between successive groups in the average weight of all the parts of the alimentary tract examined are highly significant statistically $(P<0.01)$. In summer, however, this difference is significant between groups $I$ and $I I$, highly significant between groups $I I$ and $I V$, but in voles in groups from $I V$ to VI the weight of all the parts

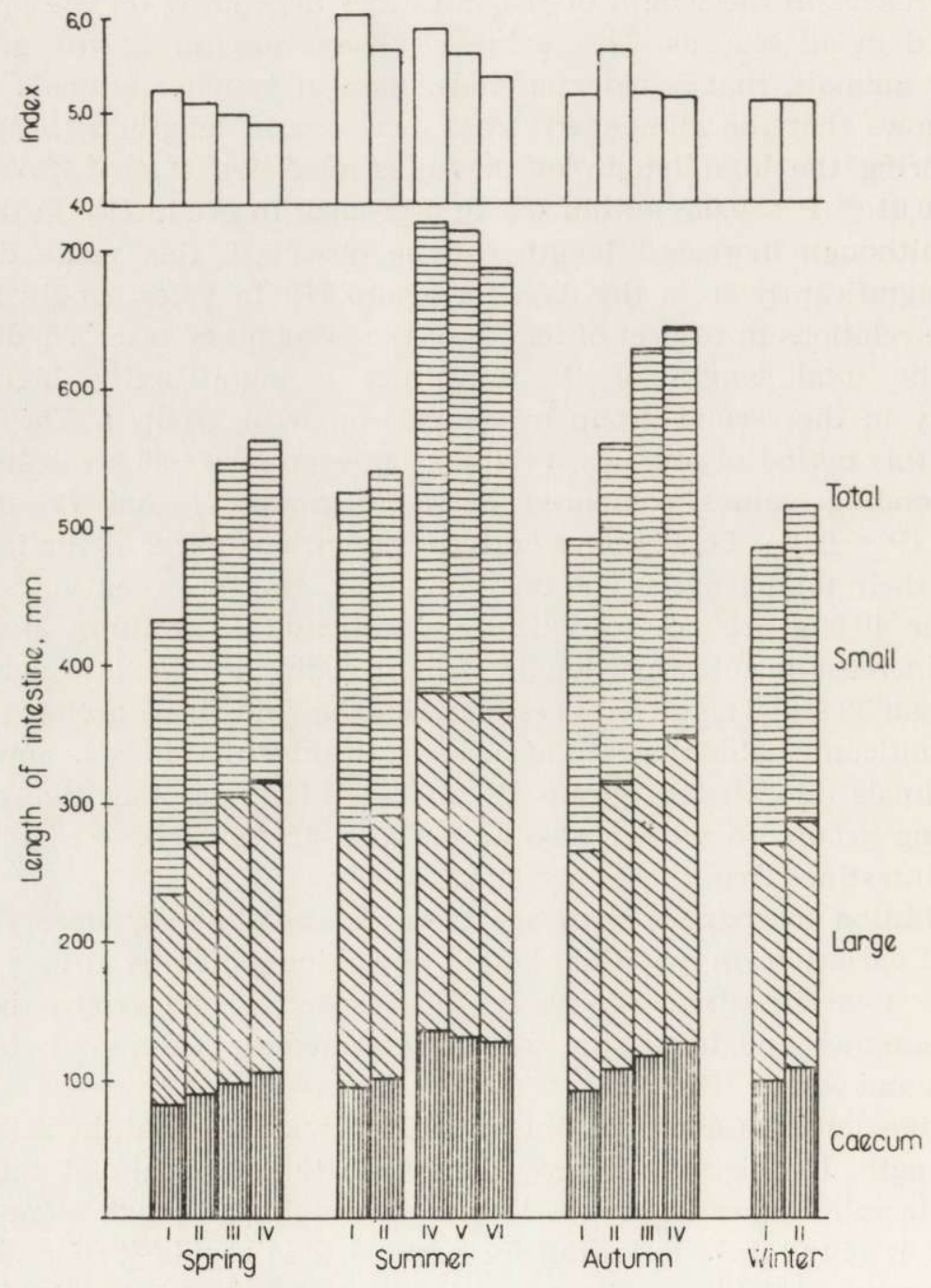

Fig. 1. Total length of intestines and their various parts in voles of different weight for the four seasons.

The index given indicates the ratio of total intestinal length to body length. Groups: $I=10.0-19.9 \mathrm{~g} ; \quad I I=20.0-29.9 \mathrm{~g} ; \quad I I I=30.0-39.9 \mathrm{~g} ; \quad I V=40.0-49.9 \mathrm{~g}$; $V=50.0-59.0 \mathrm{~g} ; V I=60.0-69.9 \mathrm{~g}$. 
examined reveals no statistically significant difference. In turn in autumn as in spring, increase in weight in successive groups is significant or highly significant.

In a similar way to that observed in respect of intestinal length seasonal differences in weight are observed, although in this case the differences

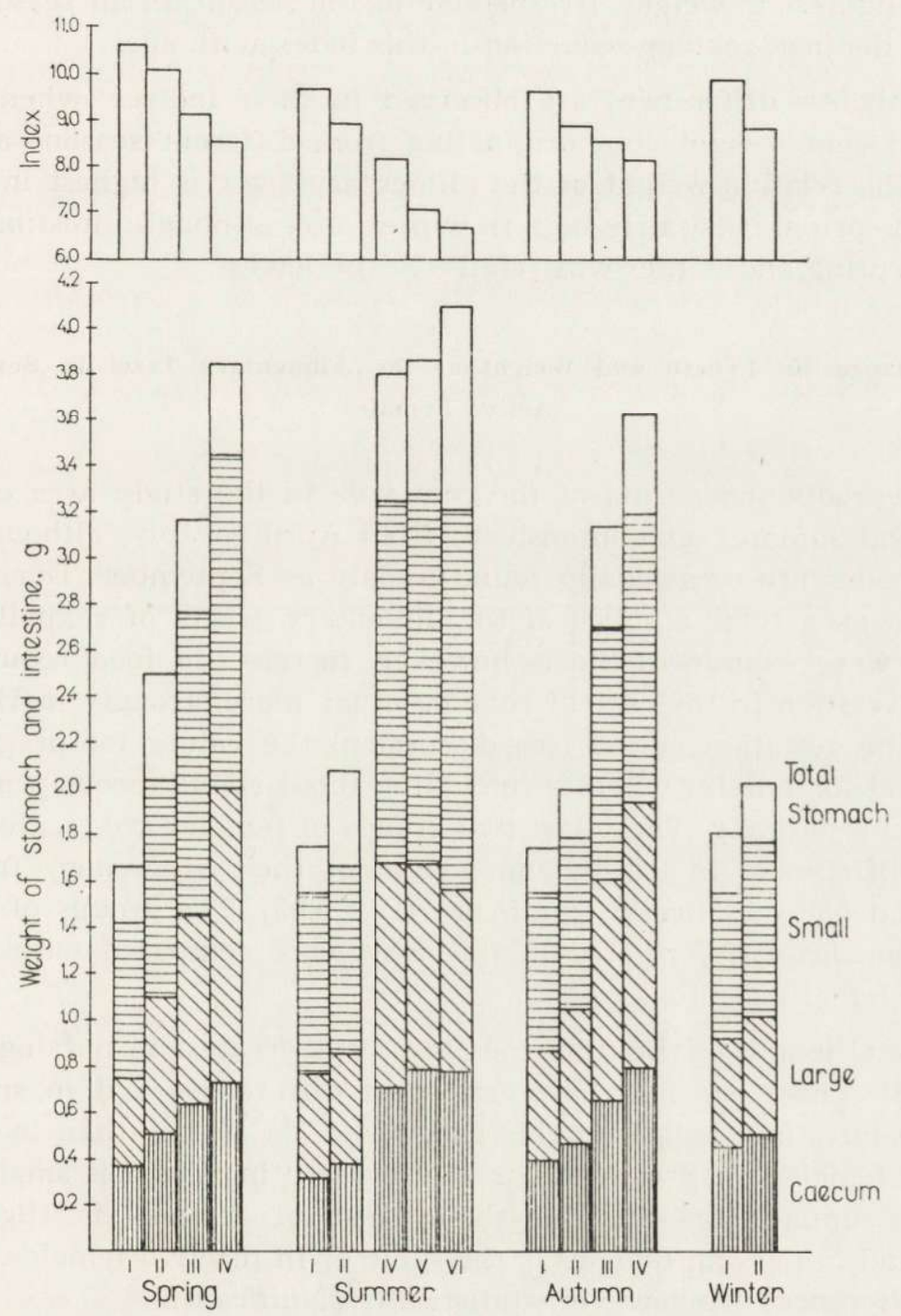

Fig. 2. Weight of alimentary tract in voles of different body weight for different seasons. Index indicates the percentage of body weight formed by weight of the alimentary tract.

Symbols of groups - see Fig. 1. 
are far smaller (Fig. 2), for instance the joint weight of stomach and intestines in group $I$ animals is similar in all seasons.

Although increase in weight of the alimentary tract with age is very distinct, it is, however, lower than rate of increase in total body weight. In this way the relative weight of these organs is highest in the group of animals lightest in weight, irrespective of the season. In all seasons there is also a distinct, regular reduction in this index with age.

Nevertheless differences are observed in their indices when groups with the same weights but originating from different seasons are compared. The relative weight of the alimentary tract is highest in group $I$ and $I I$ in spring. It is fairly high in winter also, although intestinal length both in spring and winter was relatively the lowest.

\section{Changes in Length and Weight of the Alimentary Tract in Sexually Active Females}

The reproduction period of the root vole in the study area occurs in spring and summer, and intensively from April to July, although pregnant females are occasionally found as late as September. During these two seasons a total number of 81 alimentary tracts of sexually active females were examined. Since, however, increase in food requirements during lactation in the case of rodents is far more strongly marked than during the gestation period (see discussion) the values for pregnant females and for nursing females (including those simultaneously pregnant) are given separately. These last two groups of females are treated jointly as the differences in length and weight of their alimentary tracts are slight and not statistically significant $(\mathrm{P}>0.05)$. The groups of sexually active females differentiated in this way were compared with sexully inactive females (Table 2).

The total length of the intestines is always greatest in nursing femoles (Table 2). These are not, however, great differences and in spring for instance intestinal length in this group is $5.7 \%$ higher than in sexully inactive females. In pregnant females increase in length is smaller, only $4.1 \%$. In summer intestinal length in pregnant females is slightly reduced, and in nursing females is the same as in inactive females. None of these differences are however, statistically significant.

The relative length of intestines is also greater in pregnant femcles than in inactive females, and in nursing females this index is even higker, but only in summer (Table 2).

In both pregnant and nursing females the length of the large and snall 
intestine increases to a very similar degree. This applies both to absolute and relative values. Length of the caecum is, however, greatest in nursing females. The gradual elongation of the caecum is clearly illustrated by its index, which increases in pregnant voles in spring by $3.5 \%$, and in nursing females by as much as $16.5 \%$. These differences are even more strongly expressed in summer, and are respectively $6.7 \%$ and $18.0 \%$.

Table 2

Length and weight of the alimentary tract and its various parts in pregnant and nursing females, in spring and summer (relative length and weight given in brackets).

\begin{tabular}{|c|c|c|c|c|c|c|c|}
\hline \multirow{2}{*}{\multicolumn{2}{|c|}{$\begin{array}{l}\text { Measurements } \\
\text { of intestines }\end{array}$}} & \multicolumn{3}{|c|}{ Spring } & \multicolumn{3}{|c|}{ Summer } \\
\hline & & $\begin{array}{l}\text { Sexually } \\
\text { inactive }\end{array}$ & Pregnant & Nursing* & $\begin{array}{l}\text { Sexually } \\
\text { inactive }\end{array}$ & Pregnant & Nursing* \\
\hline \multirow{4}{*}{ 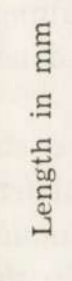 } & Large & $\begin{array}{c}245 \pm 23 \\
(2.26)\end{array}$ & $\begin{array}{c}255 \pm 20 \\
(2.30)\end{array}$ & $\begin{array}{c}259 \pm 22 \\
(2.33)\end{array}$ & $\begin{array}{c}334 \pm 23 \\
(2.73)\end{array}$ & $\begin{array}{c}326 \pm 27 \\
(2.74)\end{array}$ & $\begin{array}{c}334 \pm 03 \\
(2.73)\end{array}$ \\
\hline & Small & $\begin{array}{c}215 \pm 28 \\
(1.98)\end{array}$ & $\begin{array}{c}216 \pm 13 \\
(2.00)\end{array}$ & $\begin{array}{l}212 \pm 18 \\
(1.94)\end{array}$ & $\begin{array}{c}248 \pm 17 \\
(2.03)\end{array}$ & $\begin{array}{l}248 \pm 25 \\
(2.10)\end{array}$ & $\begin{array}{l}253 \pm 18 \\
(2.09)\end{array}$ \\
\hline & Caecum & $\begin{array}{c}102 \pm 08 \\
(0.94)\end{array}$ & $\begin{array}{c}109 \pm 14 \\
(0.99)\end{array}$ & $\begin{array}{c}117 \pm 16 \\
1.05)\end{array}$ & $\begin{array}{c}132 \pm 27 \\
(1.02)\end{array}$ & $\begin{array}{c}139 \pm 27 \\
(1.17)\end{array}$ & $\begin{array}{c}149 \pm 25 \\
(1.21)\end{array}$ \\
\hline & Total & $\begin{array}{l}562 \pm 19 \\
(5.20)\end{array}$ & $\begin{array}{c}572 \pm 31 \\
(5.33)\end{array}$ & $\begin{array}{c}588 \pm 33 \\
(5.31)\end{array}$ & $\begin{array}{l}714 \pm 47 \\
(5.84)\end{array}$ & $\begin{array}{c}713 \pm 61 \\
(5.98)\end{array}$ & $\begin{array}{c}733 \pm 64 \\
(6.02)\end{array}$ \\
\hline \multirow{5}{*}{$\begin{array}{l}\infty \\
\Xi \\
\vec{c} \\
\frac{\overrightarrow{0}}{\sigma} \\
\vec{b}\end{array}$} & Stomach & $\begin{array}{l}42 \pm 07 \\
(1.24)\end{array}$ & $\begin{array}{l}47 \pm 07 \\
(1.33)\end{array}$ & $\begin{array}{l}50 \pm 09 \\
(1.44)\end{array}$ & $\begin{array}{l}60 \pm 07 \\
(1.21)\end{array}$ & $\begin{array}{l}61 \pm 09 \\
(1.18)\end{array}$ & $\begin{array}{l}65 \pm 08 \\
(1.27)\end{array}$ \\
\hline & Large & $\begin{array}{c}144 \pm 37 \\
(4.30)\end{array}$ & $\begin{array}{c}140 \pm 21 \\
(3.98)\end{array}$ & $\begin{array}{c}152 \pm 31 \\
(4.41)\end{array}$ & $\begin{array}{c}155 \pm 28 \\
(3.17)\end{array}$ & $\begin{array}{c}181 \pm 22 \\
(3.50)\end{array}$ & $\begin{array}{c}180 \pm 28 \\
(3.45)\end{array}$ \\
\hline & Small & $\begin{array}{l}73 \pm 16 \\
(2.16)\end{array}$ & $\begin{array}{l}83 \pm 15 \\
(2.31)\end{array}$ & $\begin{array}{l}82 \pm 03 \\
(2.36)\end{array}$ & $\begin{array}{l}96 \pm 10 \\
(1.96)\end{array}$ & $\begin{array}{l}98 \pm 16 \\
(1.87)\end{array}$ & $\begin{array}{c}105 \pm 21 \\
(1.99)\end{array}$ \\
\hline & Caecum & $\begin{array}{l}68 \pm 09 \\
(2.00)\end{array}$ & $\begin{array}{l}74 \pm 13 \\
(2.07)\end{array}$ & $\begin{array}{l}81 \pm 09 \\
(2.33)\end{array}$ & $\begin{array}{l}76 \pm 10 \\
(1.50)\end{array}$ & $\begin{array}{l}83 \pm 12 \\
(1.60)\end{array}$ & $\begin{array}{l}88 \pm 14 \\
(1.77)\end{array}$ \\
\hline & Total & $\begin{array}{c}326 \pm 47 \\
(9.71)\end{array}$ & $\begin{array}{l}345 \pm 49 \\
(9.71)\end{array}$ & $\begin{array}{l}365 \pm 02 \\
(10.57)\end{array}$ & $\begin{array}{c}388 \pm 02 \\
(7.95)\end{array}$ & $\begin{array}{c}420 \pm 29 \\
(8.14)\end{array}$ & $\begin{array}{c}439 \pm 40 \\
(8.35)\end{array}$ \\
\hline
\end{tabular}

*) Nursing = nursing + nursing and simultaneously pregnant females.

The weight of the examined parts of the alimentary tract also increases successively in the three groups distinguished (Table 2) in both spring and summer. Most intensive increase is observed in the weight of the caecum, since in both spring and summer it significantly differs statistically in nursing females $(\mathrm{P}<0.05)$ from the caecum in inactive females. Thus although an increase in both length and weight of the intestinal walls and the stomach is observed in both seasons, these differences were significant only in the case of the caecum. 


\section{DISCUSSION}

The data given above show that in the root vole the length and weight of the alimentary tract increase with age, but this increase progresses more slowly than growth of the whole body. Similar changes with age were also observed in the bank vole ( $\mathrm{M} \mathrm{y} \mathrm{r} \mathrm{c} \mathrm{h} \mathrm{a,} \mathrm{1964).} \mathrm{Therefore} \mathrm{the} \mathrm{ali-}$ mentary tract in lighter younger animals is relatively greater than in heavier older voles. This differenze is undoubtedly connected with increased metabolic rate in younger voles ( $\mathrm{G} \mathrm{ę} \mathrm{b} \mathrm{c} \mathrm{z} \mathrm{y} \mathrm{ń} \mathrm{s} \mathrm{k} \mathrm{a,} \mathrm{1970),} \mathrm{involving}$ the necessity for increased consumption of food. This would therefore be the same mechanism which causes increase in the length and weight of the alimentary tract in sexually active females. This is also shown by the fact that indices of young individuals and pregnant or nursing females are in many cases similar to each other. The value of the intestinal length index in relation to total length of head and body given by $\mathrm{V}$ or o $\mathrm{nt} \mathrm{s} \mathrm{o} \mathrm{v}$ (1962) is exactly the same as in young voles weighing $23.52 \mathrm{~g}$ in summer. This author does not, however, give the age of the animals examined nor the season during which they were caught.

Differences in the weight and length of the alimentary tract are observed not only depending on age, but also on the season. These differences may perhaps be explained by the changing food supply. The amount of food and the species composing it vary to a considerable degree in the area inhabited by the animals studied although differences between

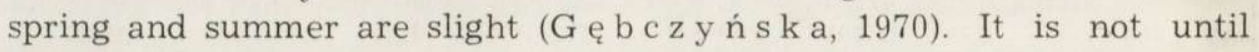
autumn that the amount of green plants forming the food supply of the vole decreases considerably, and reaches its minimum in the final period of winter.

Despite these considerable fluctuations there is always an excess of food available in relation to the energy requirements of the study population (G ębczyńska, 1970). The amount of food cannot therefore be the factor which governs these changes. It may be assumed that its quality plays a more important part here, although there are no convincing proofs of this.

With other species of rodents a relation is found between the kind of food and the morphological properties of the animals' alimentary tracts ( $\mathrm{S}$ c h w a r z, 1960; Vor on ts ov, 1961). This phenomenon is particularly clearly evident when comparing populations from geographically distant regions. Seasonal variations are, nevertheless found, most distinct in those species consuming food which undergoes extreme variations during the annual cycle (Vorontsov, 1961).

The considerable changes observed in the size of the caecum depending on age and the season of the year reflect variations in digestive ca- 
pacity. The caecum plays a special role in the digestion of high cellulose content food, that is, food peculiar to the root vole. Variations in the length and weight of this part of the alimentary tract are thus directly connected with the animal's diet. Although considerable increase in the length and weight of the caecum is observed at all seasons during the puberty of voles, the indices for young animals are always clearly higher.

Trojan \& Wojciechowska (1967) and Migula (1969) found that females of Microtus arvalis ( $\mathrm{P}$ a 11 a s, 1779), a vole with similar food requirements to $M$. oeconomus, increase their energy requirements during both gestation and lactation. During gestation food consumption increases on an average by $32 \%$, and during lactation by $133 \%$, in comparison with non-reproducing females ( $\mathrm{M} \mathrm{ig} \mathrm{u} \mathrm{la,} \mathrm{1969).} \mathrm{It} \mathrm{could} \mathrm{be} \mathrm{assumed} \mathrm{from} \mathrm{this}$ that nursing females have higher morphological parameters of the alimentary tract than pregnant females.

This assumption is generally confirmed, since the length and weight of the alimentary tract are greater in pregnant than in sexually inactive females and are greatest in nursing females (Table 2). If we consider variations in the different parts of the alimentary tract the regularity of variations in the length of the caecum is striking. It must be emphasised here, however, that pregnant females differ relatively little in respect of this character from inactive females, while it is only in nursing females that there is considerable increase in this value. It may therefore be assumed that the $1 / 3$ increase in energy requirements during gestation does not bring about morphological changes. The increase in energy used during this period is undoubtedly provided for by physiological mechanisms. It is not until this value increases enormously (up to $233 \%$ ) during the lactation period that it involves the necessity for morphological change in the alimentary tract. Nevertheless increase in length and weight is not in proportion to the increase in food consumption. It may therefore be concluded that in this case also the most important role is played by intensification of the function of the alimentary tract and not its structural changes.

The change in weight and length of the alimentary tract during gestetion and lactation is smaller in the root vole than in other species of rodents. In nursing female rats the weight of the stomach between the 12 th and 20 th day of lactation is $20 \%$ greater than in controls. The average weight of the small intestine of rats between the 12 th and 20 th days of lactation inclusive was 77 per cent greater than the average weight in virgin control rats (F ell et al., 1963). Increase in the weight of the small and large intestines, the caecum and stomach in sexually active female bank voles was $22.7 \%$ ( $\mathrm{M} \mathrm{y} \mathrm{cha}, 1964)$, in female yellowActa theriol. 24 
-necked field mice - 39.0\% ( $\mathrm{M} \mathrm{y} \mathrm{r} \mathrm{c} \mathrm{h} \mathrm{a,} \mathrm{1965).} \mathrm{In} \mathrm{the} \mathrm{root} \mathrm{vole} \mathrm{in} \mathrm{sum-}$ mer the increase in this value in pregnant females was $19.0 \%$, and in nursing females $-23.7 \%$. In spring, on the other hand, the weight of the alimentary tract in inactive individuals is greater than in pregnant, and only minimally less than in nursing females.

The weight of the stomach in rats fed on a concentrated diet (wheat, barley, fish meal and meat) formed $0.6 \%$ of the whole body weight (F ell et al., 1963). The stomach of the yellow-necked field mouse, a typical seed-eating species, forms $0.9 \%$ of the whole weight ( $\mathrm{M} \mathrm{y} \mathrm{r-}$ $\mathrm{ch}$ a, 1965), and in the bank vole, feeding on both seeds and bulky food - the stomach forms approximately $1.5 \%$ of the body weight (M y r$\mathrm{ch}$ a, 1964), whereas the weight of the stomach in the root vole varies in different weight groups and varies correspondingly from 1.0 to $1.44 \%$. The change in the weight index of the alimentary tract depending on the species' diet is particularly clear when the intestines and stomach are treated jointly. In the yellow-necked field mouse this index is $4.35 \%$ (M y r ha, 1965), in the bank vole from 6.5 to 7.8\% (M y r c ha, 1964), and in the root vole varies from 7.3 to $10.0 \%$.

If the phenomenon of increase in length and weight of the alimentary tract during gestation and lactation in females of different species is compared the conclusion is reached that it is most strongly expressed in species in which the size of the alimentary tract is relatively small. In species eating bulky food the relative size of the alimentary tract is large and during gestation and lactation the change, although visible, is smaller than in species with relatively smaller alimentary tracts.

Acknowledgements: We wish to thank Dr. Z. P ucek for his criticism and suggestions concerning preparations of the manuscript.

\section{REFERENCES}

1. Buchalczyk T. \& Pucek Z., 1968: Estimations of the numbers of Microtus oeconomus using the Standard Minimum method. Acta theriol., 13, 29: 461 -482 .

2. Fell B. F., Smith K. A. \& Campbell R. M., 1963: Hypertrophic and hyperplastic changes in the alimentary canal of the lactating rat. J. Pathol. Bacteriol., 85, 1: 179-188.

3. G ę b c z y ńska Z., 1970: Bioenergetics of a root vole population. Acta theriol., 15, 3: $33-66$.

4. Migula P., 1969: Bioenergetics of pregnancy and lactation in the European common vole. Acta theriol., 14, 13: 167-179.

5. Myrcha A., 1964: Variations in the length and weight of the alimentary tract of Clethrionomys glareolus (S chreber, 1780). Acta theriol., 9, 10: 139 -148 . 
6. Myrcha A., 1965: Length and weight of the alimentary tract of Apodemus flavicollis (M e l c h i or, 1834). Acta theriol., 10, 16: 225-228.

7. S c h warz S. S., 1960: Nekotorye zakonomernosti ekologičeskoj obuslovennosti interernyh osobennostej nazemnyh pozvonočnyh. Tr. In-ta Biol. Uralsk. Fil. AN SSSR, 14: 113-177.

8. Trojan P. \& Wojciechowska B., 1967: Resting metabolism rate during pregnancy and lactation in the European common vole - Microtus arvalis (P a 11.). Ekol. pol. A, 15, 44: 811-817.

9. Vorontsov N. N., 1961: Ekologičeskie i nekotorye morfologičeskie osobennosti ryžih polevok (Clethrionomys Tilesius) evropejskogo severo-vostoka. Tr. Zool. In-ta, 29: 101-136.

10. Vorontsov N. N., 1962: The ways of food specialization and evolution of the alimentary system in Muroidea. Symp. theriol., Brno, 1960: 360-377.

11. Vorontsov N. N., 1967: Evolucija piščevaritelnoj sistemy gryzunov. Izd. "Nauka» Sibir. otd.: 1-235. Novosibirsk.

Accepted, March 29, 1971.

Mammals Research Institute,

Polish Academy of Sciences,

Białowieża, woj. Białystok.

\section{Zofia GĘBCZYŃSKA i Marek GĘBCZYŃSKI}

\section{DEUGOSĆ I CIĘŻAR PRZEWODU POKARMOWEGO U NORNIKA POENOCNEGO}

\section{Streszczenie}

Na 282 osobnikach nornika północnego Microtus eoconomus Pallas, 1776 dokonano pomiarów długości i ciężaru przewodu pokarmowego, w różnych sezonach (Tabela 1). Były to zarówno osobniki młode, niedojrzałe płciowo, jak i dorosłe, dojrzałe płciowo, w tym samice ciężarne i karmiące. Długość i ciężar przewodu pokarmowego zwiększa się z wiekiem, jednakże wzrost ten postępuje wolniej niż wzrost całego ciała (Fig. 1, 2). U młodych norników przewód pokarmowy jest relatywnie większy niż u osobników starszych. U samic karmiących długość i ciężar jelit i żołądka są wyższe niż u ciężarnych (Tabela 2).

Porównując zmiany w wielkości przewodu pokarmowego zachodzące $w$ okresie ciąży i laktacji u różnych gatunków gryzoni stwierdzono, że są one największe u tych gatunków, które odżywiają się paszą treściwą, a wielkość ich przewodu pokarmowego jest względnie mała. Do tej grupy zaliczyć można szczura oraz mysz wielkooką leśną. Natomiast u nornicy rudej, gatunku o mieszanym reżimie pokarmowym hypertrofia w okresie ciąży jest mniej wyraźna. Najsłabiej jest ona wyrażona u nornika północnego, typowego trawożercy o dużym przewodzie pokarmowym. 